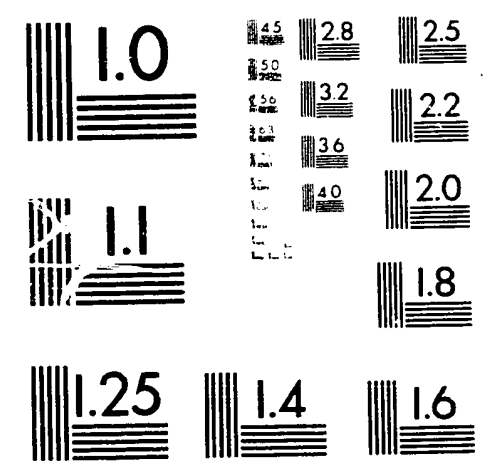



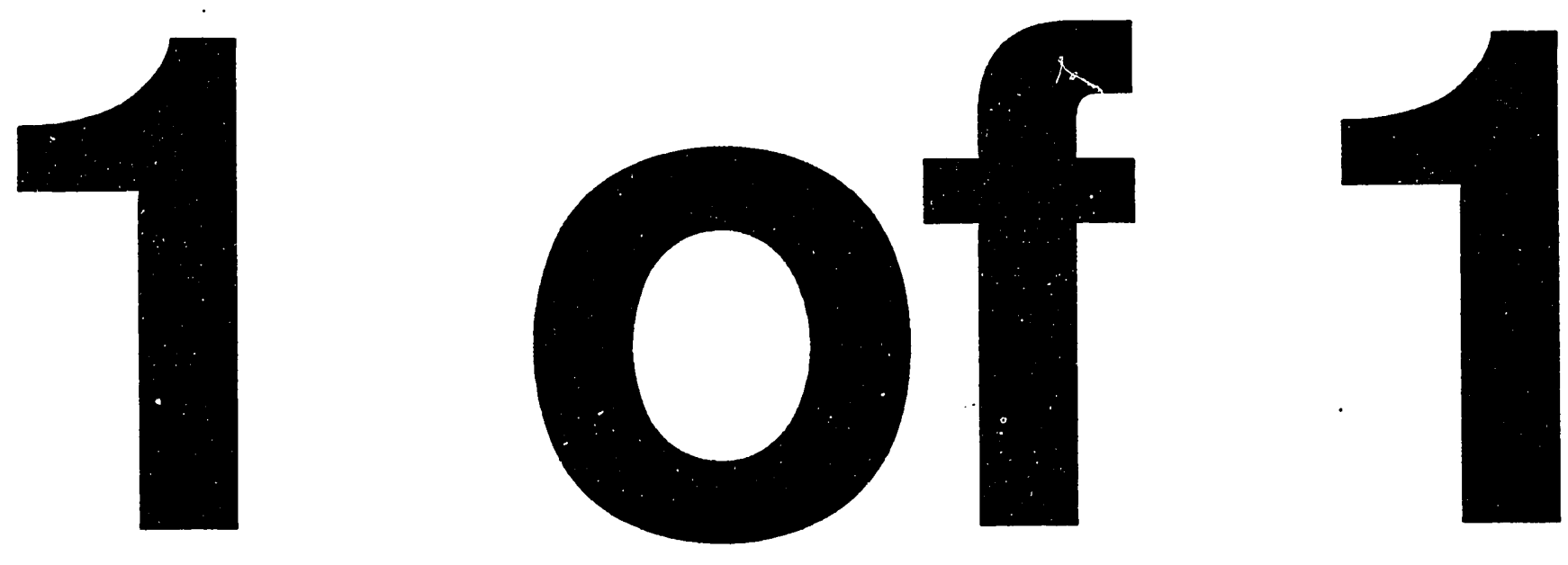


\section{DETAILED ANALYSIS OF A RCRA LANDFILL FOR THE UNITED NUCLEAR CORPORATION DISPOSAL SITE \\ AT THE OAR RIDGE Y-12 PLANT \\ OAR RIDGE, TENNESSEE}

Prepared for:

Martin Marietta Energy Systems, Inc. Y-12 Environmental Restoration Division oak Ridge, Tennessee

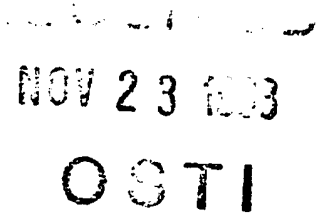

April 1991

Prepared by:

\section{Science Applications International Corporation Oak Ridge, Tennessee}

\section{DISCLAIMER}

This report was prepared as an account of work sponsored by an agency of the United States Government. Neither the United States Gnvernment nor any agency thereof, nor any of their employees, makes any warranty, express or implied, or assumes any legal liability or responsibility for the accuracy, completeness, or usefulness of any information, apparatus, product, or process disclosed, or represents that its use would not infringe privately owned rights. Reference herein to any specific commercial product, process, or service by trade name, trademark, manufacturer, or otherwise does not necessarily constitute or imply its endorsement, recommendation, or favoring by the United States Government or any agency thereor. The views and opinions of authors expressed herein do not necessarily state or reflect those of the United States Government or any agency thereof. 


\author{
DETAILED ANALYSIS OF A RCRA LANDFILI. \\ for the \\ UNITED NOCLEAR CORP. DISPOSAL SITE \\ at the \\ OAR RIDGE Y-12 PLANT, OAR RIDGE, TENNESSEE
}

CONTENTS

1.0 INTRODUCTION . . . . . . . . . . . . . . . . . . . . 1

l.1 RCRA Landfill Alternative................... . 1

I.2 Description of the RCRA Landfill and Cap . . . . . . . . . 2

1.3 Site-specific Preparation and Construc ion . . . . . . . . 4

I.4 Short-Term Effectiveness . . . . . . . . . . . . . . 6

2.5 Long-Term Effectiveness and Permanence . . . . . . . . . 8

1.6 Reduction of Toxicity, Mobility, and Volume . . . . . . . . 10

1.7 Implementability ... . . . . . . . . . . . . 10

1.8 Cost Analysis . . . . . . . . . . . . . . . 11

1.9 Compliance with arars . . . . . . . . . . . . . . . 12

1.10 Overall Protection of Human Health and the Environment . . . 12

1.11 state Acceptance ................... 12

1.12 Community Acceptance .................. 12

\title{
FIGURES
}

1

Conceptual RCRA Landfill Design. . . . . . . . . . . 3

TABLES

1 Detailed Analysis of RCRA. 


\section{DETAILED ANALYSIS OF A RCRA LANDFILL \\ for the \\ UNITED NUCLEAR CORP. DISPOSAL SITE \\ at the \\ OAR RIDGE Y-12 PLANT, OAR RIDGE, TENNESSEE}

\subsection{INTRODUCTION}

The purpose of this detailed analysis is to provide a preliminary compilation of lata, information, and estimated costs associated with a RCRA landfill alternative for UNC Disposal site. This is in response to Environmental protection Agency (EPA) comment No. \#6 from their review of a "Feasibility Study for the United Nuclear Corporation Disposal Site at the Oak Ridge Y-12 Plant, Oak Ridge, Tennessee."

\subsection{RCRA Landfill Alternative}

The RCRA landilil conceptual design presented herein is in accordance with the requirements specified in Subtitle D of RCRA and the Tennessee Solid waste Rules. Subtitle $D$ of RCRA establishes the framework for Federal, state and local government cooperation in controlling the management of nonhazardous solid waste. Subtitle $D$ of RCRA provides minimum standards for protecting human health and the environment. The UNC Disposal Site wastes have been classified as non-hazardous as reported in the previously referenced Feasibility study.

This alternative involves the handing and removal of the wastes from the UNC Disposal site and relocating them at a RCRA landfill that would be constructed within the property boundaries of the Y-12 plant. After all waste is removed from the UNC Disposal Site, the site will be closed and secured. Once the wastes are placed in the RCRA landfill, a RCRA cap will be constructed to permanently encapsulate the wastes.

Prior to construction activities, a site selection study would be required to identify suitable locations for the on-site landfill. This would entail preliminary environmental assessments of selected sites to determine geotechnical, hydrogeologic, and site suitability characteristics. When alternative sites are identified, an in-depth environmental impact assessment would be required, as well as development of design plans and specifications for the preferred RCRA landfill site and cap.

The design and performance objectives of a RCRA Landfill and final cap are to minimize liquid infiltration through the landfill cap, minimize liquid 
exfiltration out of the landfill base, promote proper crainage, minimize erosion, accommodate setting and subsidence, and ensure permanent encapsulation of the wasles.

RCRA Subtitle D specifies design requirements consisting of a composite liner system using a flexible membrane liner (FML) overlying 3 ft of compacted soil with a hydraulic conductivity no greater than $1 \times 10^{-7} \mathrm{~cm} / \mathrm{sec}$. The Tennessee Solid Waste Rules state that underlying this composite liner shall be a geologic buffer which shall have a maximum hydraulic conductivity no greater than $1 \times 10^{-6}$ $\mathrm{cm}$ ! sec and measures not less than 5 ft from the bottom of the liner to the seasonal high water table of the uppermost unconfined aquifer.

A cetailed analysis in section 4.2 of the "Feasibility study for the United Nuclear Corporation Disposal Site at the Oak Ridge Y-12 Plant, Oak Ridge, Tennessee" describes a modified RCRA cap alternative to cover the waste at its present location. A similar cap would be used to permanently seal the UNC Disposal site wastes at the RCRA landfill.

\subsection{Description of the RCRA Landfill and Cap}

Typically, landfills are constructed by excavating the native soils as close to the seasonal high groundwater as allowed by state and federal regulations. The walls of the open excavation generally have interior sideslopes ranging from $1: 1$ to 2:1. The bottom of the landfill will be constructed to minimum slopes, with minimum groundwater separation distances and with the intent of maximizing landfill volume. At the ground surface, earthen berms of low-permeability soils are typically constructed around the landfill. Iiner anchor trenches are excavated on the outside of the berms to secure the synthetic liner. These berms also prevent sufface water runon into the landfill and establish the limits of the waste disposal area.

As depicted in Figure 1, the base liner system will be separated from the seasonal high water table by a minimum of $5 \mathrm{ft}$ of a compacted low-permeability soil with a maximum hydraulic conductivity of $1 \times 10^{-6} \mathrm{~cm} / \mathrm{sec}$. Determination of in-situ permeabilities below the composite base liner will be conducted as part of the preliminary hydrogeologic assessments. The base liner system will consist of a minimum of 3 ft of a compacted low-permeability soil with a maximum hydraulic conductivity of $1 \times 10^{-7} \mathrm{~cm} / \mathrm{sec}$. Overlying this $3-f t$ layer will be a $60 \mathrm{mil}$ high-density polyethylene (HDPE) synthetic liner with a 24 in. covering of a protective/drainage sand layer. The base of the landfill will be graded at a minimum slope of 28 to facilitate arainage of leachate. Perforated collection 


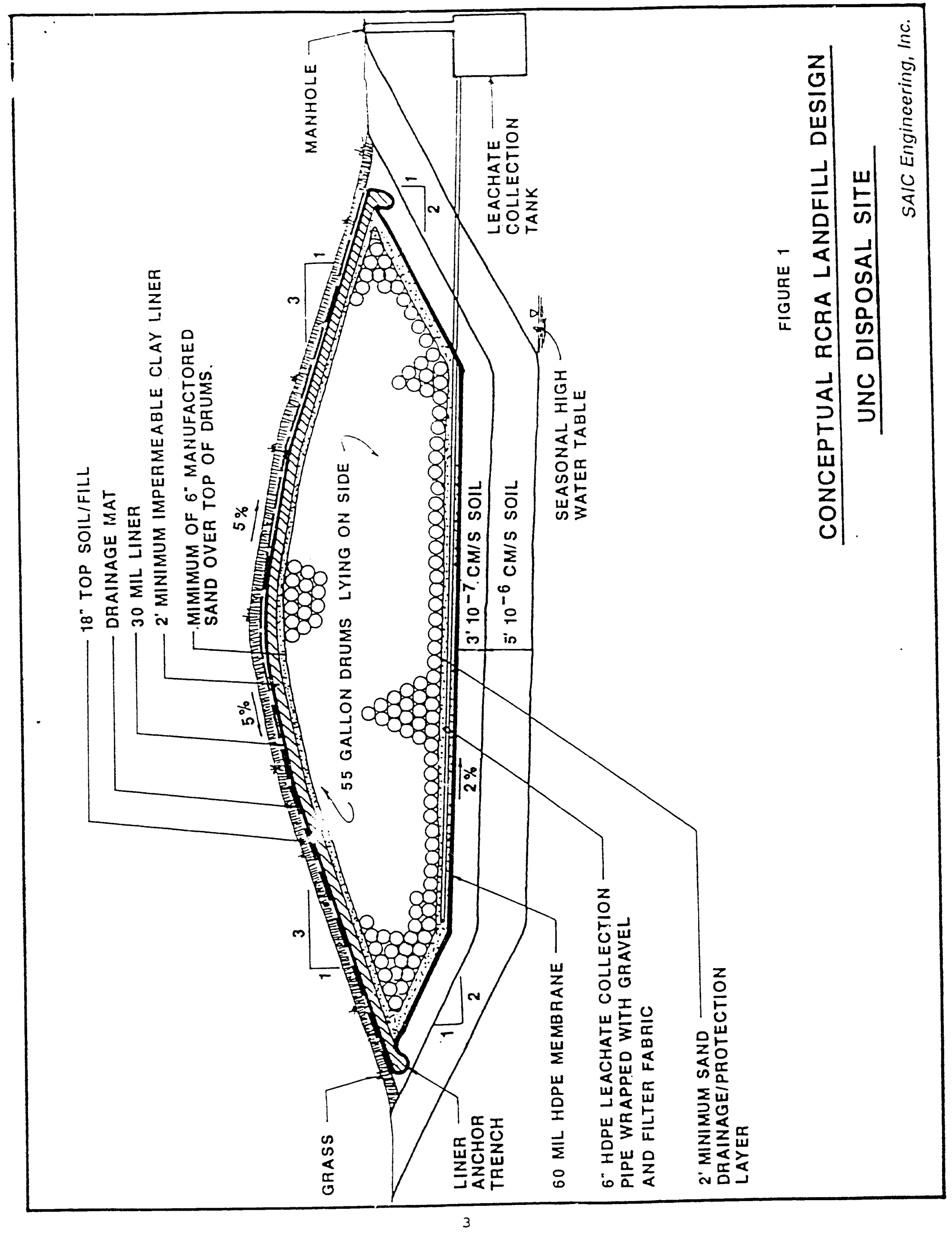


ines will be placed directly on the synthetic liner and encased in a gravel bed and wrapped in filter fabric. These collection lines will be located within the protective/drainage sand layer and will transport leachate via gravity to a 10,000 gal leachate holding tank (Fig. 1).

upon completion of the waste placement within the RCRA landfill, a mirimum 24-in. thick compacted soil layer will be placed over the wastes. Local clays removed during the excavation of the RCRA landfill will be used for construction of this layer, provided the soil can meet the required design permeability. The soil will be placed in 6-in. lifts and will be compacted and contoured to maximize zunoff and minimize infiltration. The final top slope of the cap will be at least 58 and the side slopes will be no steeper than a maximum ratio of three horizontal to one vertical $(3: 1)$.

A suitable synthetic membrane ( $30 \mathrm{mil}$ thick) will be placed ovor the clay. This synthetic membrane will provide an additional low-perineability boundary to prevent water from infiltrating and will deform withcut rupturing if settling occurs. The synthetic liners for the landfill base and the landfill cap will be sealed together within the anchor liner trench.

A polyethylene drainage geonet placed over the $30 \mathrm{mil}$ membrane will provide lateral drainage from the synthetic membrane and prevent flooding or pooling of surface water. A polypropylene filter fabric will be placed over the drainage layer to protect it from the downward migration of soil fines from the vegetative cover layer. An 18-in.-thick vegetative cover soil layer will be installed using local, loosely packed soils to support grass cover.

\subsection{Site-specific Preparation and Construction}

The preparation of the RCRA landfill for the landfilling of UNC Disposal site wastes will be divided into phases with each phase consisting of the following components:

1. Preparation of the subgrade conditions to maintain an adequate vertical separation from the maximum groundwater table and minimum slopes;

2. The construction of a composite impermeable liner and overlying drainage layer on the base and sides of the landfill base to contain leachate generated by the facility;

3. The installation of a leachate collection system, which will include a network of perforated collection pipes on top of the liner and leachate storage tanks; 
4. The construction of drainage improvements designed to minimize leachate generation and soil erosion;

Ffter constructing the RCRA landfill at the y-12 plant, activities will be conducted to prepare for closure of the existing disposal site, consisting of removing, transferzing, and placing the UNC Disposal Site wastes within the RCRA iandeill.

Drums will be handled via a drum-grappling device on a large track-driven excavating machine. This type of handling equipment minimizes personnel involvement and reduces the risk of ruptured or mishandled drums. Demolition m.terials will be repackaged in 55-gal drums for low-level radioactively contaminated materials. Due to the potential for exposure to low-level radioactivity, appropriate personal protective equipment and site monitoring will be required. Transport of wastes is assumed to be by tractor-trailer truck. zransport distance from the UNC Disposal site to the RCRA landfill at the Y-i2 plant is assumed to be 10 miles.

Once the wastes are removed from the current disposal site, soil samples will be taken from the floor of the excavation to confirm that the soil is not cortaminated. After confirmation, the UNC Disposal site will be backfilled with clean soil and returned to a natural state. If soil contamination is confirmed after testing, these soils will be excavated and drummed for disposal in the RCRA Landfill.

At the RCRA landfill, the drummed wastes will be placed on their sides upon the sand drainage layer. Once the bottom layer of drums is set in place, a minimum of $6 \mathrm{in.}$ of manufactured sand (limestone sand and fly ash) will be placed over the drums, upon which the next layer of drums will be placed. All void spaces between the drums will be filled by this procedure. This step will be repeated until all drummed wastes are placed within the RCRA landfill.

Once all wastes are placed within the RCRA landfill, the surface area will be prepared for closure. Closure of the landfill will consist of the following components:

1. Preparation of the landfill surface to ensure the appropriate compaction and grades are achieved;

2. Construction of a two-ft-thick compacted soil (clay) layer to be placed over the sand surface at the appropriate grades;

3. Installation of the FMI over the ciay; 


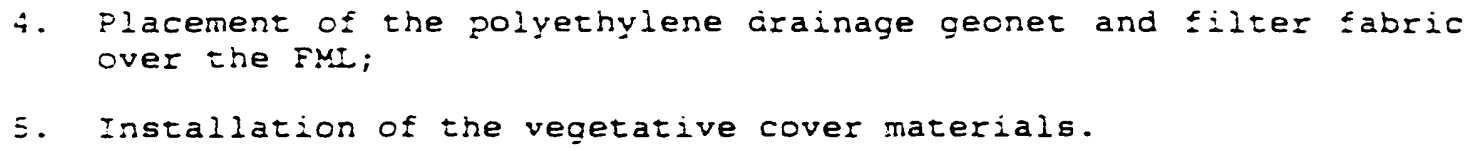

The following sections present an assessment of the RCRA landfill and cap using ine evaluation cziteria: long- and short-term effectiveness; reduction of coxicity, mobility, and volume; protection of human health and the environment; compliance with ARARs; implementability and cost; and state and community acceptance. A summary of the nine criteria is presented in Table 1.

\subsection{Short-Term Effectiveness}

The RCRA landfill and cap alternative has a low short-term effectiveness because : involves a significant amount of handing of drummed wastes with a resulting potential exposure of plant personnel to contaminants and the risk of injury wrile removing and tzansferring the wastes from the UNC Disposal site and indfilling the wastes at the newly constructed RCRA landfill. Although appropriate safety precautions would be enforced and mechanized equipment used to tre extent possible, the potential will exist for drum ruptures and falling or sliding drums. Miscellaneous waste materials will primarily be moved by hand, thereby further increasing the risk of injury or exposure to workers. Also, some portion of solidified wastes that may be spilled from deteriorated drums will require handling and packaging by hand. Repackaging of uncontained or spilled wastes and contaminated soils and the potential for drum rupture increase the isk of fugitive dusts and emigsions and consequently exposure of personnel.

The time required for implementation ( 12 months) assumes that using two crews, 80 drums per day of solidified wastes can be removed from the UNC Disposal Site, iransierred and placed in the RCRA landiill. Each crew would include four personnel consisting of a drum-grappler device operator and three ground crew members. One crew would be stationed at the UNC Disposal site to load the drums on to the tractor trailer. The other crew would be stationed at the RCRA landfill to unload and deposit the drums within the RCRA landfill. Additional personnel may be required for repackaging miscellaneous wastes and containerizing contaminated soils, if such are present from the base of the existing UNC Disposal site.

iazards associated with exposure of workers to contaminants during the construction of the RCRA landfill and the final cap and closure of the UNC Disposal sice will be minimal. During construction, workers on site will follow the safety measures included in the site-specific health and safety plan. The p:imary environmental impacts resulting from the implementation of this alterna$91-028 P / 0491$ 


\begin{tabular}{|c|c|}
\hline $\begin{array}{l}\text { Short-term } \\
\text { effectiveness }\end{array}$ & $\begin{array}{l}\text { Low short-term effectiveness due to handling, } \\
\text { movement and placement of wastes. Increased risk of } \\
\text { exposure to site workers from fugitive dusts. } \\
\text { Injury risk present due to drum handling and } \\
\text { packaging of miscellaneous wastes. }\end{array}$ \\
\hline $\begin{array}{l}\text { Long-terw } \\
\text { effectiveness } \\
\text { and permanence }\end{array}$ & $\begin{array}{l}\text { High degree of long-term effectiveness } \\
\text { if proper testing, construction techniques, } \\
\text { and an effective maintenance and inspection } \\
\text { program are followed. }\end{array}$ \\
\hline $\begin{array}{l}\text { Reduction of } \\
\text { toxicity, } \\
\text { mobility, and } \\
\text { volume }\end{array}$ & $\begin{array}{l}\text { Reduces mobility of contaminants by } \\
\text { encapsulating and isolating the wastes from } \\
\text { tho underlying aquifer system. This } \\
\text { alternative minimizes further leachate } \\
\text { production and potential future } \\
\text { contamination of groundwater. }\end{array}$ \\
\hline Implementability & $\begin{array}{l}\text { Technically and administratively feasible. } \\
\text { Site preparation and final selection of } \\
\text { Fan materials requires compatibility testing, } \\
\text { planning and engineering. Design must plan for } \\
\text { minimizing leachate ponding witbin the landfill } \\
\text { and minimize all potential voids witbin the } \\
\text { waste pile to prevent subsidence of the cap. }\end{array}$ \\
\hline \multirow[t]{2}{*}{ Cost } & 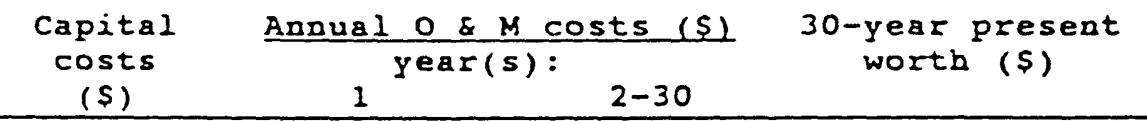 \\
\hline & $\begin{array}{l}2,542,325 \quad 97,200 \quad 73,400 \quad 3,252,100 \\
\text { Capital costs include design, engineering, and } \\
\text { contingency a llowances. o \& costs are variable, } \\
\text { depending on duration of component processes. }\end{array}$ \\
\hline $\begin{array}{l}\text { Compliance with } \\
\text { ARARS }\end{array}$ & $\begin{array}{l}\text { Action-, location-and chemical-specific ARARs are } \\
\text { met at implementation of alternative. }\end{array}$ \\
\hline $\begin{array}{l}\text { Overall } \\
\text { protection of } \\
\text { buman bealth and } \\
\text { the environment }\end{array}$ & $\begin{array}{l}\text { High degree of protection of human health and } \\
\text { environment. }\end{array}$ \\
\hline State acceptance & $\begin{array}{l}\text { Specific state comments of the features of this } \\
\text { alternative are not available at present. }\end{array}$ \\
\hline $\begin{array}{l}\text { Community } \\
\text { acceptance }\end{array}$ & $\begin{array}{l}\text { Specific community comments of the features of this } \\
\text { alterative are not available at present. }\end{array}$ \\
\hline
\end{tabular}


Live are dust emissions from the transportation, excavation and grading of clean backfill and cover materials. Dust emissions may be controlled by using a water iruck to spray the soils to keep them moist or by applying calcium chloride or aust suppressant foams.

The remedial response objectives are achieved almost immediately upon completion of the RCRA landfill cap construction. The expected time for completion of this alternative is 24 months, which includes 6 months for final design and environmental permitting of the RCRA Landfill, 3 months to construct the RCRA Landfill, 12 months to remove, transfer, and relandfill the wastes, and 3 months to sap the RCRA landfill and close the UNC Disposal site. These time frames do not include the time required to conduct the preliminary environmental assessments, hydrogeological assessments, or environmental impact studies zequired as part of the site selection process.

\subsection{Long-Term Effectiveness and Permanence}

The long-term effectiveness of the RCRA landfill and cap alternative is directly related to the quality assurance/qualizy control (QA/QC) procedures conducted during the construction of the laadfill and cap. A deficiency in the construction of the landfill base liner and/or cap would regult in water infiltration and leachate exfiltration, allowing transport of contaminants from the waste material to underlying soils, and, ultimately, to the groundwater. Failure in the integrity of the FML due to leachate incompatibility is also a concern.

The RCRA landfill and cap will likely meet or exceed its long-term performance specifications if constructed properly and if QA/QC standards are followed. Synthetic membranes have not been in use long enough to have an observable design life. However, in the absence of sunlight, oxygen, or stresses of any kind, a properly formulated, compounded, and manufactured FMI will stay intact indefinitely. The effects of low-level radiation associated with the leachate from these waste materials on the FMI needs to be evaluated. The lowpermeability soils are susceptible to hydrocarbon solutions, acidic or basic solutions, and freezing. The properties of the clay that determine its design life include the degree of compaction and water content. The built-in redundancy of the multimedia base liner and cap reduces the probability of failure.

Long-term management, operation, and maintenance is important to maintaining the integrity of the RCRA landfill and cap. A qualified individual or firm will perform periodic inspections at regular intervals. The site inspections will include documentation of precipitates on the ground, odors, intermittent seeps, $91-028 P / 0491$ 
soft spots, erosional defects, depressions and puddles, subsidence, and signs of vegetative stress or robust growth. Some potential long-term problems may include erosion, an inadequate drainage and/or leachate collection system, slope failure, subsidence, differential settlement, flooding, vegetation failure, frost disturbance, cracking, plugging of porous soil, and deterioration of synthetics. Foutine inspections will identify these and other problems, and immediate repairs will be possible. The vegetative cover will be maintained and groomed periodically, and soil reconditioning will be done as necessary to perpetuate the vegetation.

Clogging is the primary cause of concern for the long-term performarce of the ieachate collection system and removal systems. Clogging can decrease the efficiency of the collection system and lead to the build-up of leachate on the FMI, which increases the residence time between the leachate and the FMI. This could ulimately increase the leakage rate of the FMI and potentially cause a release of contaminants to the underiying low-permeability soils. Particulate clogging can occus in a number of locations, namely the sand drainage layer, drainage gravel, of filter fabric that surrounds the collection pipes. Clogging may also occur as a resuit of biological growth formation. To periodically test the leachate collected for total solids, total dissilved solids, total suspended sulids, and biological oxygen demand would determine if clogging was occurring. If the concentrations of these parameters increased over time, a high pressure water-flush with a biocide to clean out the filter and drain would be required for relieving particulate and biological clogging. However, the amount of leachate collected should be minimal over time due to a finite amount of lic:id contained in the wastes and because the majority of the wastes will be drur ned in secure 55-gallon drums.

Replacement of the cap or components of the cap will eventually be ne: ..:y. If the landfill and cap are constructed properly, there is a high degree of confidence that the periodic inspections and leachate testing will reveal any potcntial problems in time for repairs to be made.

In general, the long-term effectiveness of the RCRA landfill and cap depends on the proper selection of the FMI, based on the results of the leachate compatibility tests and maintaining proper $Q \mathrm{~A} / \mathrm{QC}$ standards during construction. ilso, an effective maintenance and inspection program will ensure that any potential problems are corrected expeditiously. Potential human health and environmental risk associated with contaminants from UNC Disposol site wastes after the construction of a RCRA landfill are less than the risks associated with implementing the modified RCRA cap alternative. 


\subsection{Reduction of Toxicity, Mobility, and Volume}

This alternative does not provide for treatment of the waste material; therefore, neither a reduction of the toxicity of the waste material nor a reduction in volume of the waste material will result. Implementation of this option would minimize leachate production and potential future contamination of groundwater by totally encapsulating the waste material and providing a system to collect leachate which may emanate from the waste.

\subsection{Implementability}

Site-specific issues and constraints related to geotechnical, hydrogeological and site suitability characteristics are not addressed in this preliminary information compilation. If this alternative is to be further considered and developed, the specific issues mentioned above must be addressed. The discussion that follows is related to the construction of RCRA landfills and caps in general.

Complications that may cause difficulties or delays in construction of the RCRA landfill and cap include wet and/or cold weather. cold weather could cause variable freezing in either the base liner material, backfill material, or the cap construction material, which may result in subsidence or differential settling. Wet weather could cause delays in construction due to difficulties in grading and compacting either the base liner, backfill, or the cap materials, in which optimum densities may not be achieved. Severe erosion can often result from heavy precipitation during construction.

The technology for constructing a RCRA landfill and cap is well known and is not likely to cause delays. However, uncertainties related to construction, which would be determined during the QA/QC testing procedures, could result in schedule delays. QA/QC procedures may reveal in-situ or placed materials not meeting specifications or improper construction techniques.

Encapsulating wastes within a RCRA landfill and cap is a generally available technology. Use of low-permeability soils and synthetic materials has been sufficiently demonstrated for new landfill construction and final closures of landfills. Similar caps for closure of waste disposal areas have been extensively used at the $y-12$ plant. No further technical development is required for this alternative; therefore, this technology is available for full-scale use if determined to be the preferred alternative. Adequate specialists and equipment are readily available for construction of the RCRA landfill and cap. 
The large number of vendors and specialisto available for implementing this technology makes competitive bidding a possibility.

\subsection{Cost Analysis}

The direct capital cost for this alternative incorporates costs for site preparation and construction of the RCRA landfill and cap (incluoing labor, materials, equipment and $Q A / Q C$ testing) and all work associated with the removal and placement of the UNC Disposal site wastes within the RCRA landfill and closure of the UNC Disposal Site. Indirect capital costs include 258 engineering and design and $a$ 318 contingency cost. The total capital cost for this alternative is $\$ 2,542,325$ (Table $A-1$ and $A-2$ in Appendix A).

The O\&M costs for the RCRA landfill and cap include groundwater monitoring, site inspections, mowing and revegetation, erosion control, drainage maintenance repairs to the cap materials and grooming equipment and leachate disposai. Other O\&M costs include project management, insurance and contingency costs. The estimated yearly maintenance cost for the landfill and cap is 573,400 (Table A-3 in Appendix A). The present-worth O\&M costs are based on a 108 discount rate and a 30-year design 1ife. The total present-worth O\&M costs for the RCRA landfill and cap are $\$ 709,800$ (Table $A-4$ in Appendix A).

The effective design life of the RCRA landfill and cap is 30 years provided that proper installation and maintenance procedures are followed. As part of the o\&M costs, an annual allowance ( 3.38 of the RCRA cap capital costs) was prorated over the 30-year design life to provide for the full replacement of all components of the cap at the end of the 30-year period.

The total capital costs for the construction of the RCRA landfill and cap are relatively insensitive to potential uncertainties that could develop over the brief period of time ( 6 months) required for the construction of the RCRA landfill and cap. Total capital costs are based on 1990 dollars and are derived from actual quantities and prices. Approximately 708 of the total capital costs for implementing this alternative will be committed during the 6-month construction period and are not dependent on future OQM costs. The remaining 308 of the total capital costs for movement and placement of the wastes within the landfill will be committed during the 12 -month mobilization effort.

The volume of the encapsulated waste will remain constant over the 30-year design life of the RCRA landfill and cap. Capital will not be expended in the future to dispose of additional contaminated materials, except to collect and dirpose of any leachate.

91-028P/0491 
sllowances have been estimated for site inspections, groundwater monitoring, mowing and revegetation, erosion control, leachate disposal, and cap maintenance and replacement. The cost estimates were made on a conservative basis to properly operate and maintain the RCRA landfill and cap. Allowances for project management, insurance and contingencies were estimated at 1 of the total capital cost of the caps. Using a discount rate of 108 and a life of 30 years, presentworth O\&M costs are $\$ 709,800$.

These costs do not include the costs associated with conducting the preliminary environmental studies consisting of geotechnical, hydrogeologic, and environmental impact assessments required to select a site for the RCRA landfill.

\subsection{Compliance with ARARs}

Action-, location- and chemical-specific ARARs are met at the time of implementing this alternative. Additional discussion of ARARs must be addressed if the alternative is given further consideration.

\subsection{Overall Protection of Euman Bealth and the Environment}

The RCRA landfill and cap offer a high degree of protection to human health and the environment. The construction of the landfill and the final cap will encapsulate the source material from direct human contact; thus, pctential impacts to human health from the UNC Disposal site wastes will be minimal. In addition, the RCRA landfill and cap, when constructed correctly, will protect the environment from releases of contaminants from the waste materials by continuously collecting leachate that may potentially leach from the wastes. The cap will minimize infiltrating water, thus minimizing the transport of contaminants to the leachate coilection system.

\subsection{State Acceptance}

Specific state comments on the features of this alternative are not available.

\subsection{Comounity Acceptance}

specific community comments on the features of this alternative are not yet available. 
APPENDIX A

COST ANALYSIS

$91-028 P / 0491$ 


\section{RCRA IANDPILI ALTERACATIVB TOTAL CAPITAL COST}

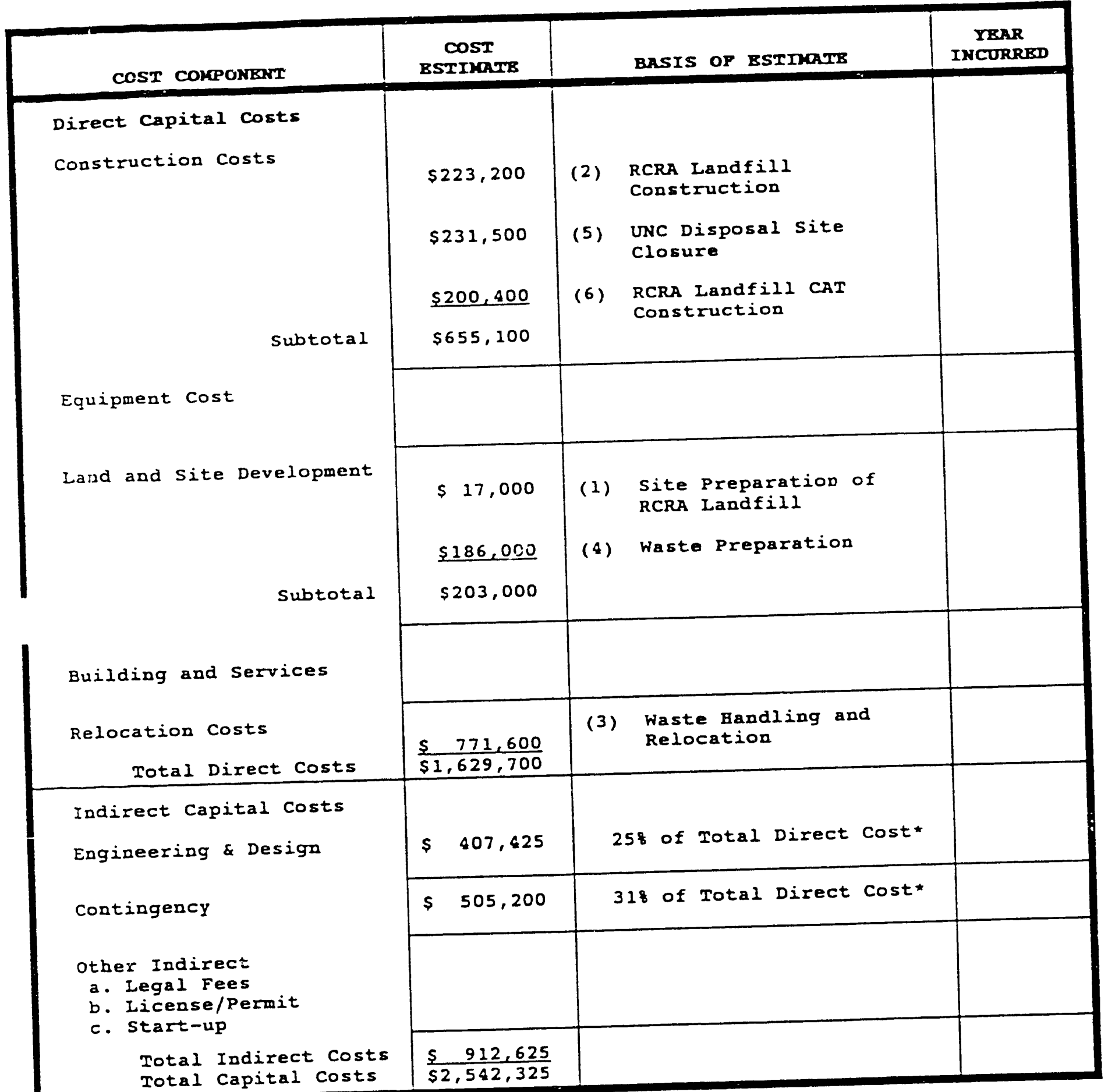

Reference: Energy Systems 


\section{RCRA IANDPILI ALTERNATIVB}

\section{BASIS OP DIRBCT COST BSTIMATB}

cosT ITBa: Direct Construction Costs

cosT Coraporenr: Equipment, Labor and Materials

BASIS: RCRA Landfill and Cap Design

CALCULATION/SOURCB: Means Site Work Cost Data, 10 Ah Annual Edition, 1991, Gundle Lining, Inc., Personal Correspondence, 1990, SAIC Engineering, Inc. Misc. Conetruction Project Costs, 1990

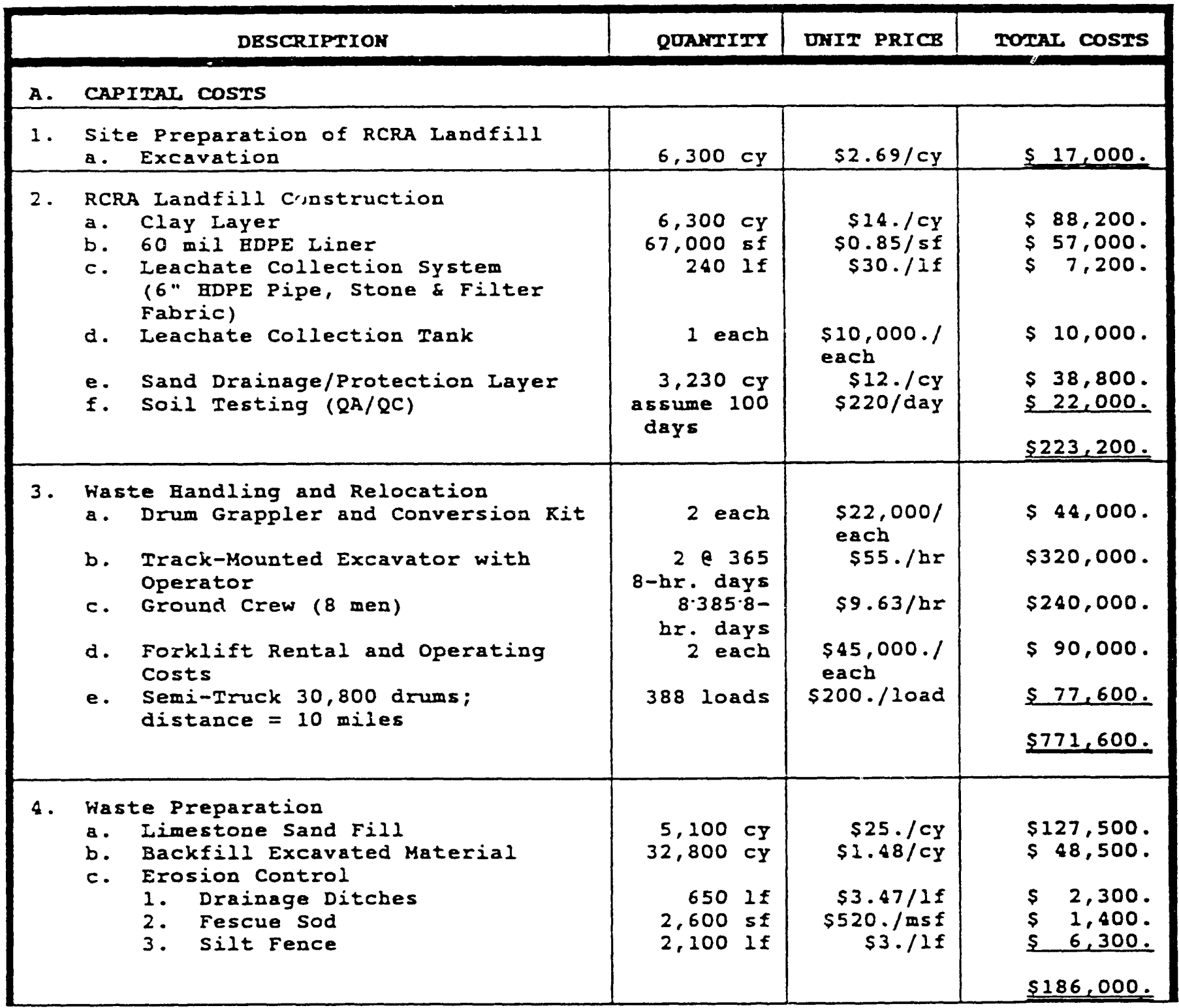


TABLB A-2 (Continued)

RCRA IANDFILL ALTERUATIVB

BASIS OF DIRBCT COST ESTIMATB

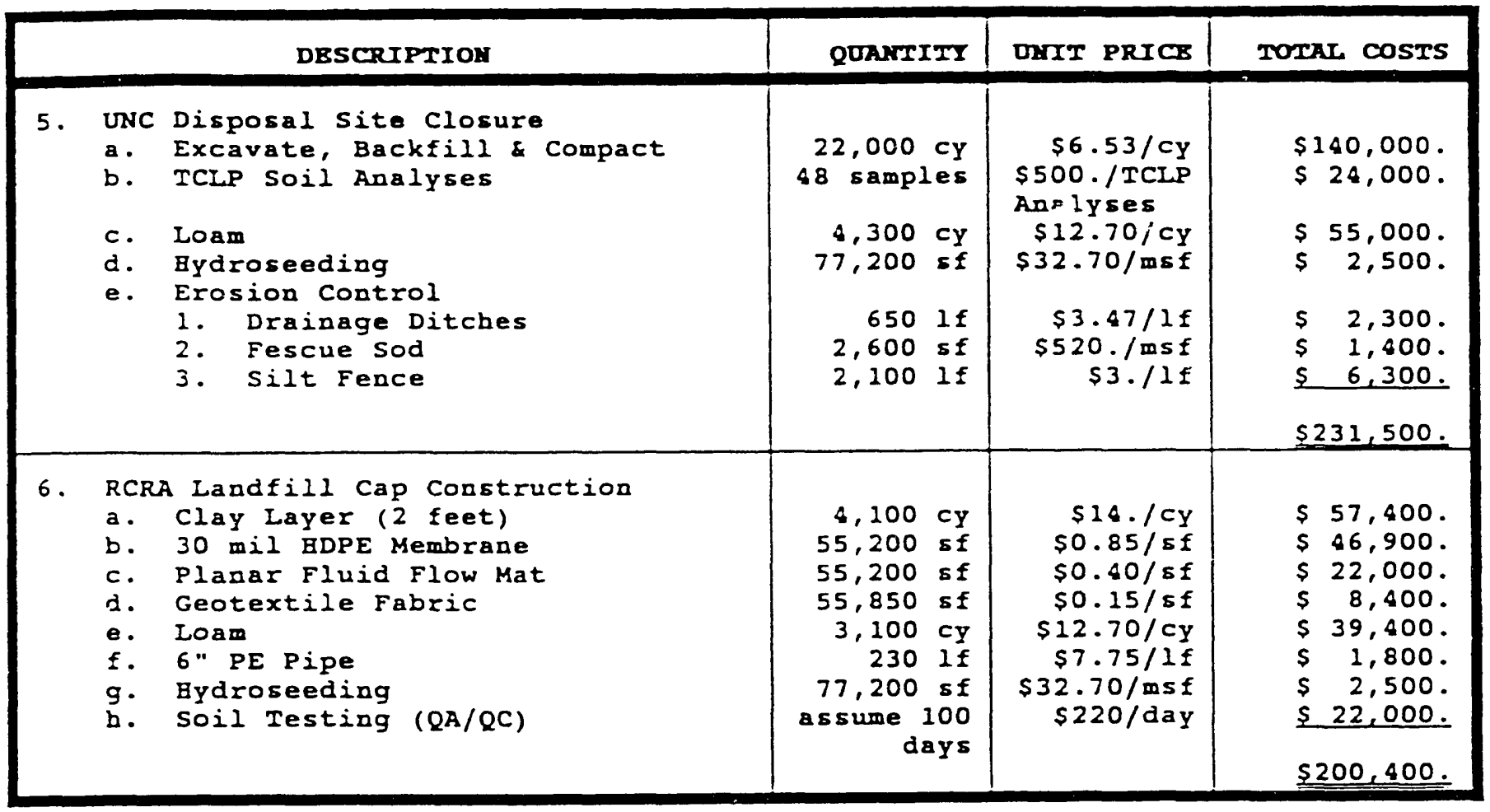




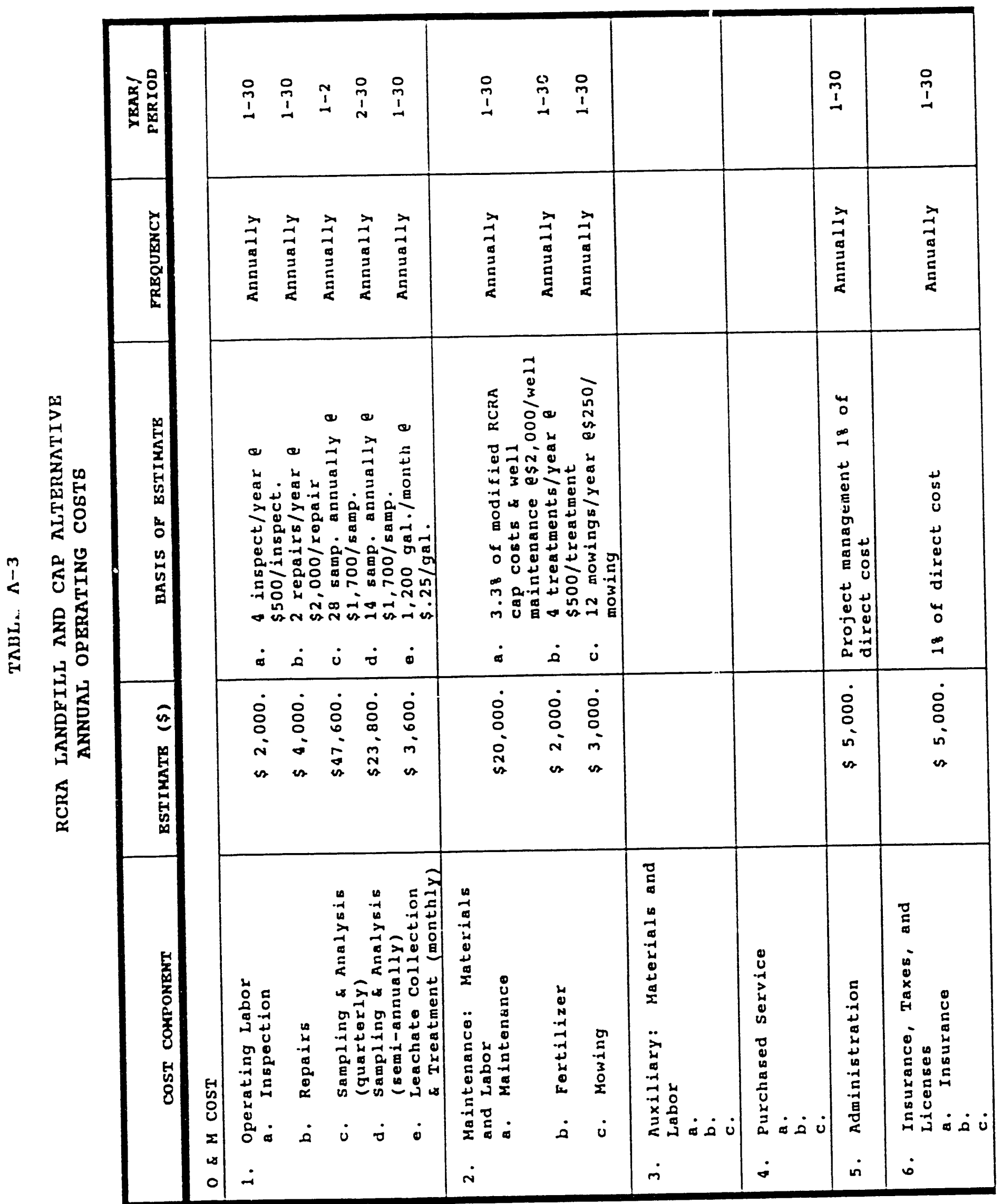




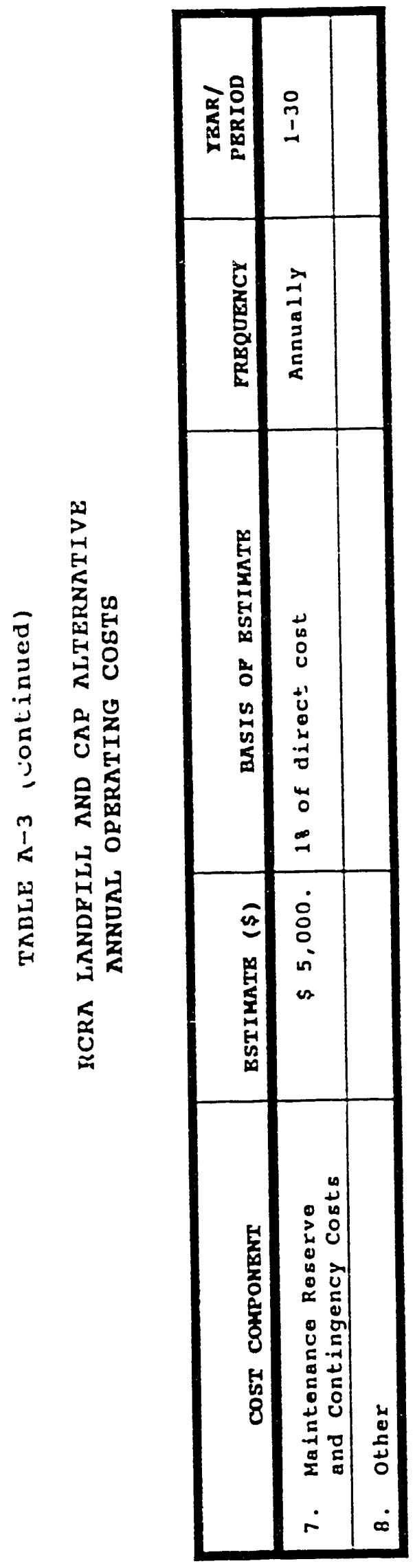




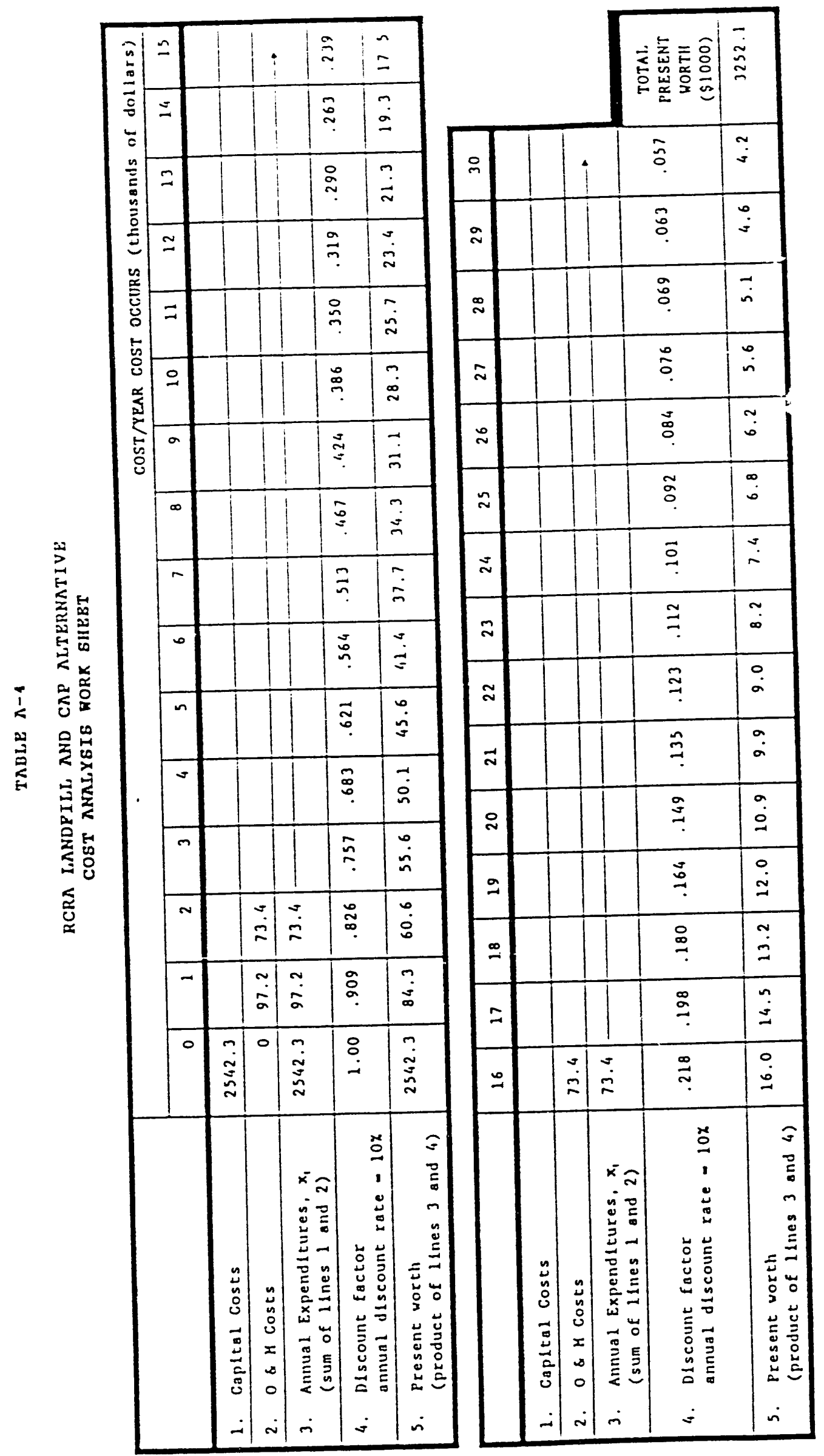


Distribution:

Recipients as designated by the author plus
A. K. Lee/DOE-OSTI (2)
Y-12 Central Files

Note: This distribution page should not be included in the copy of your document (abstract, visuals, article, etc.) submitted to a journal or technical society. 

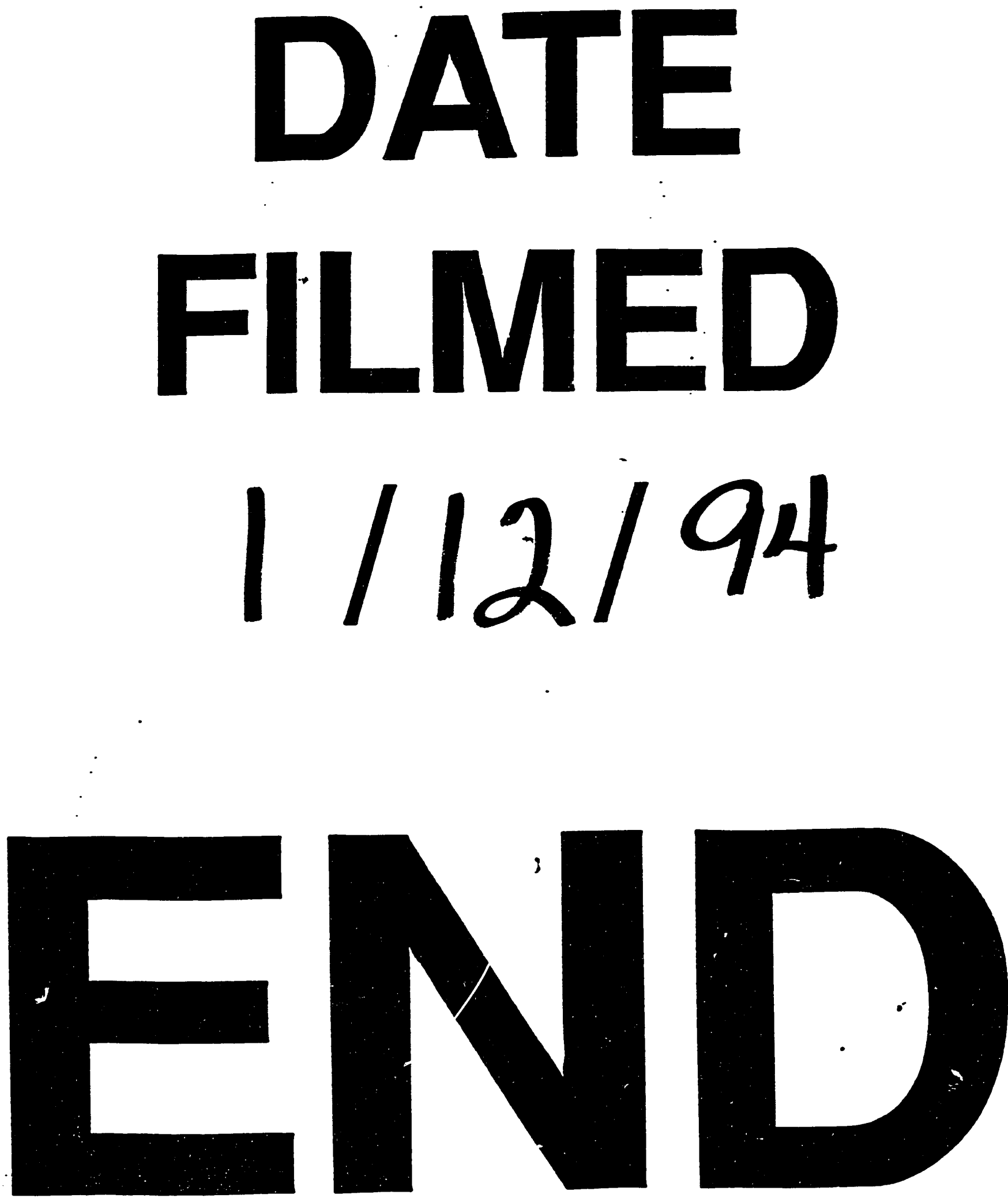



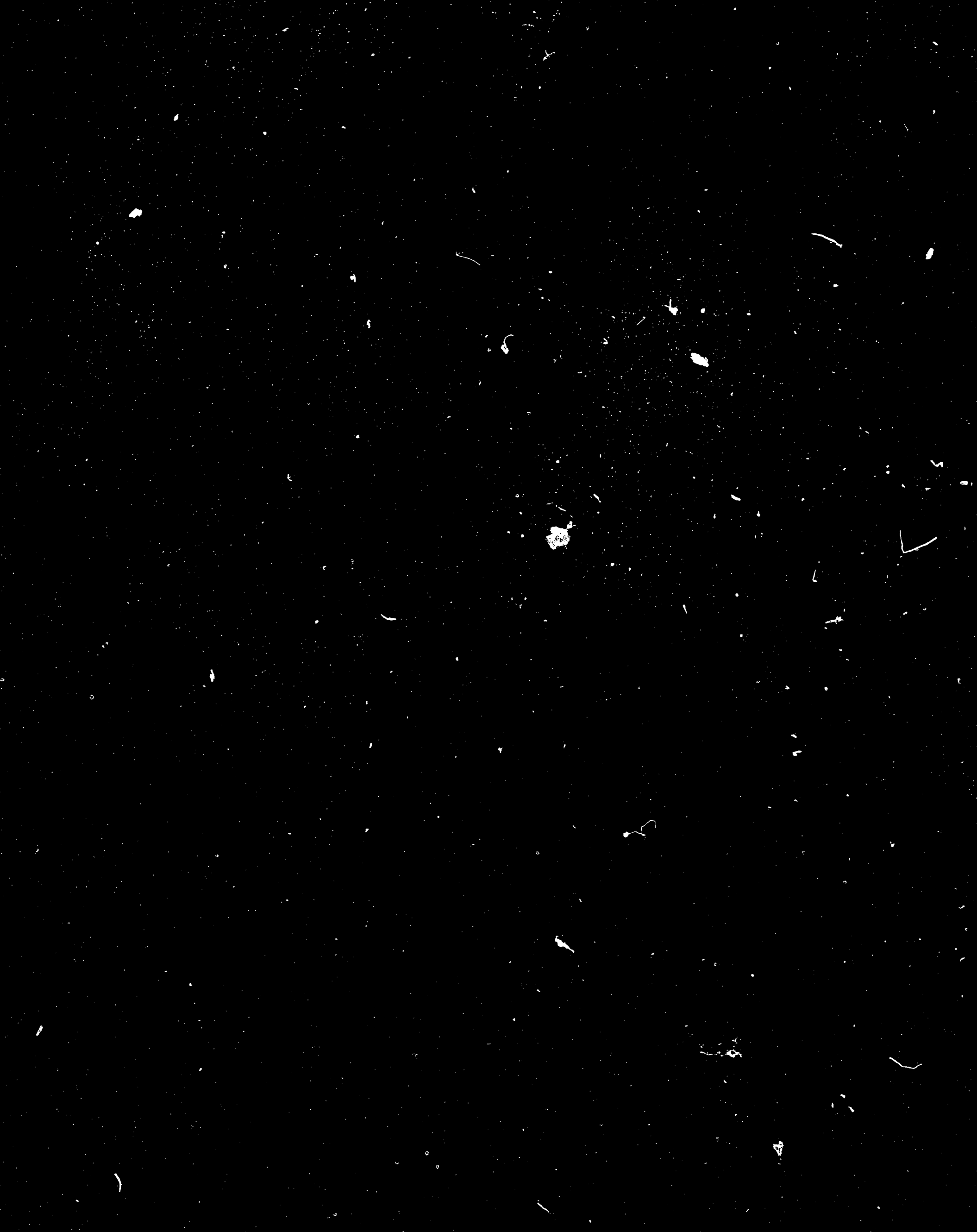


3 

$\therefore \quad+\infty$
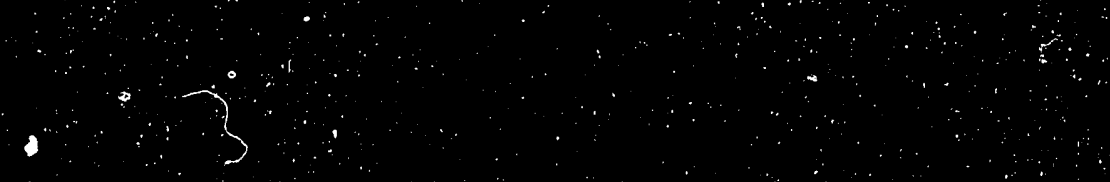

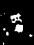

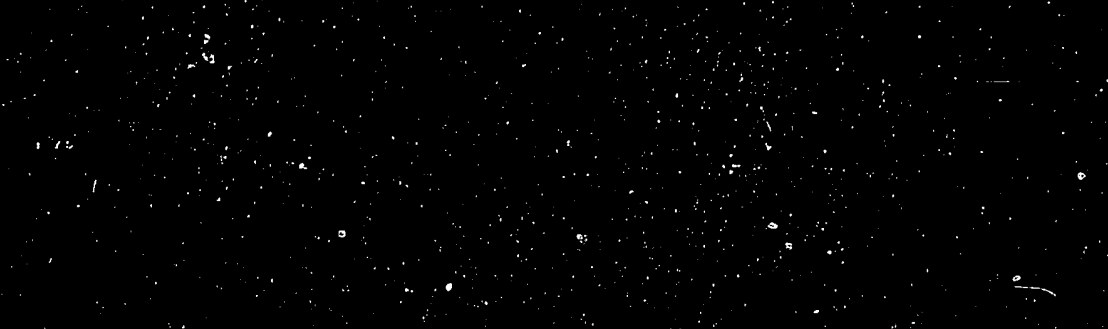




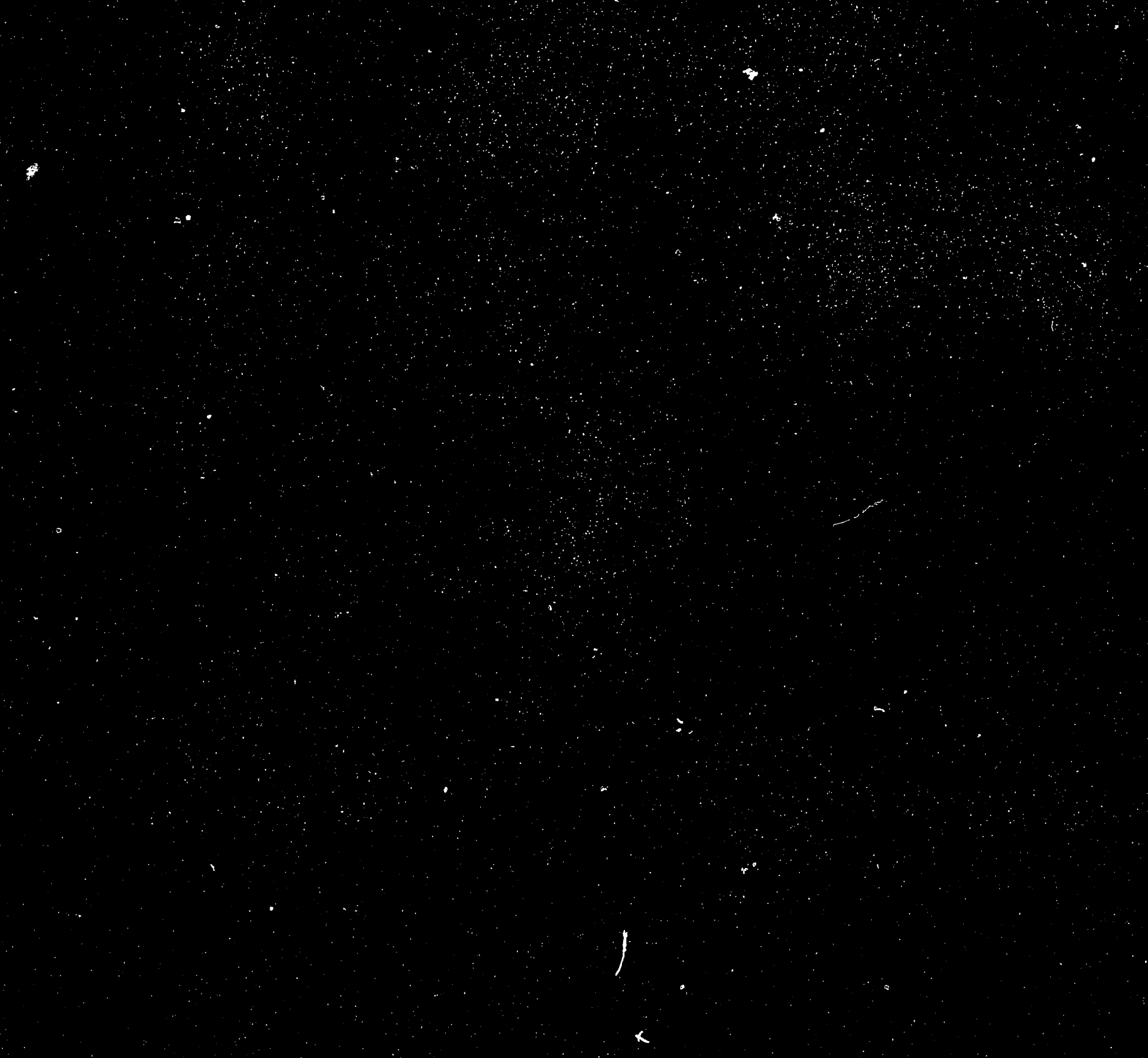




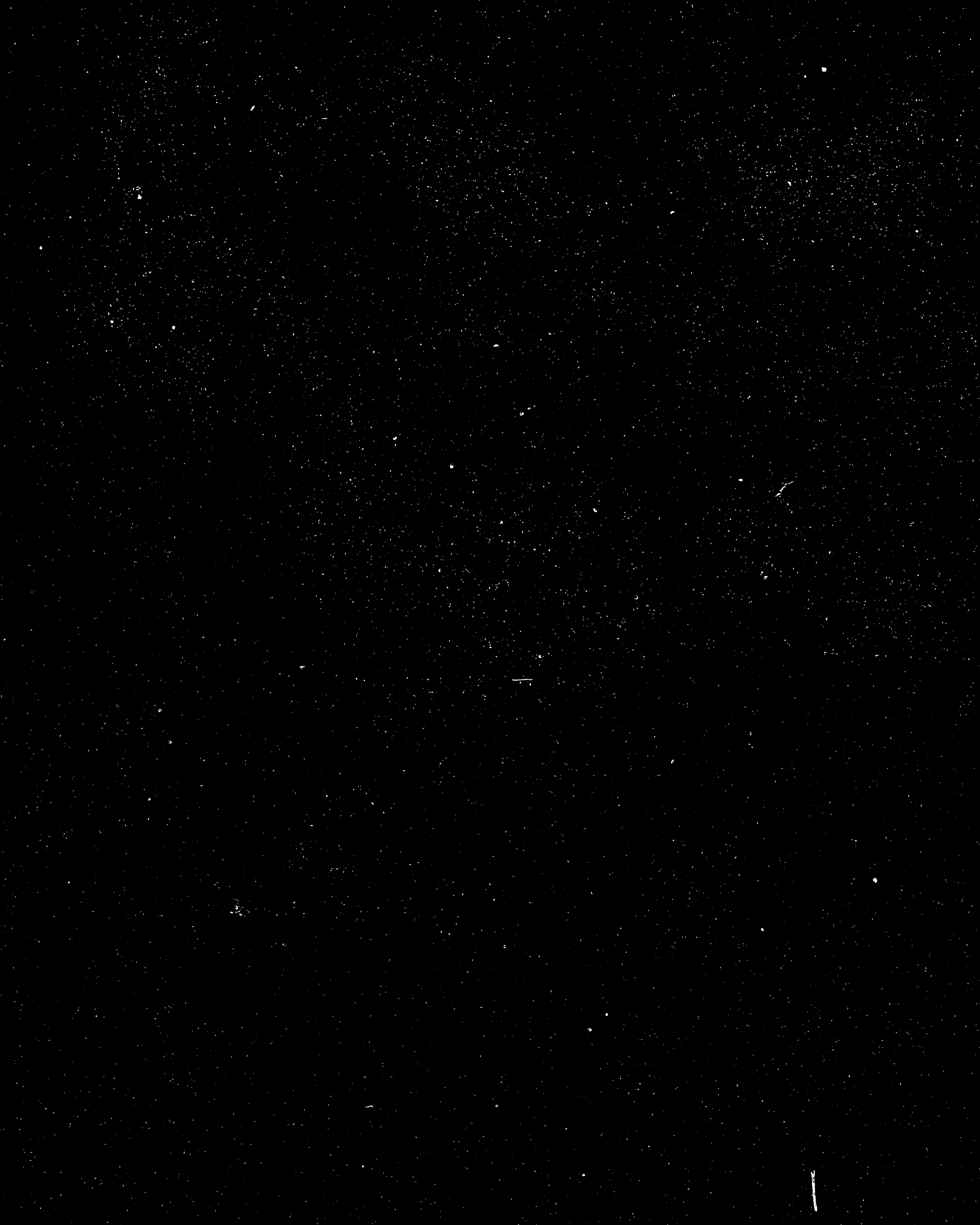


$-\quad+$

1 



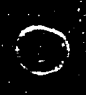

$?$
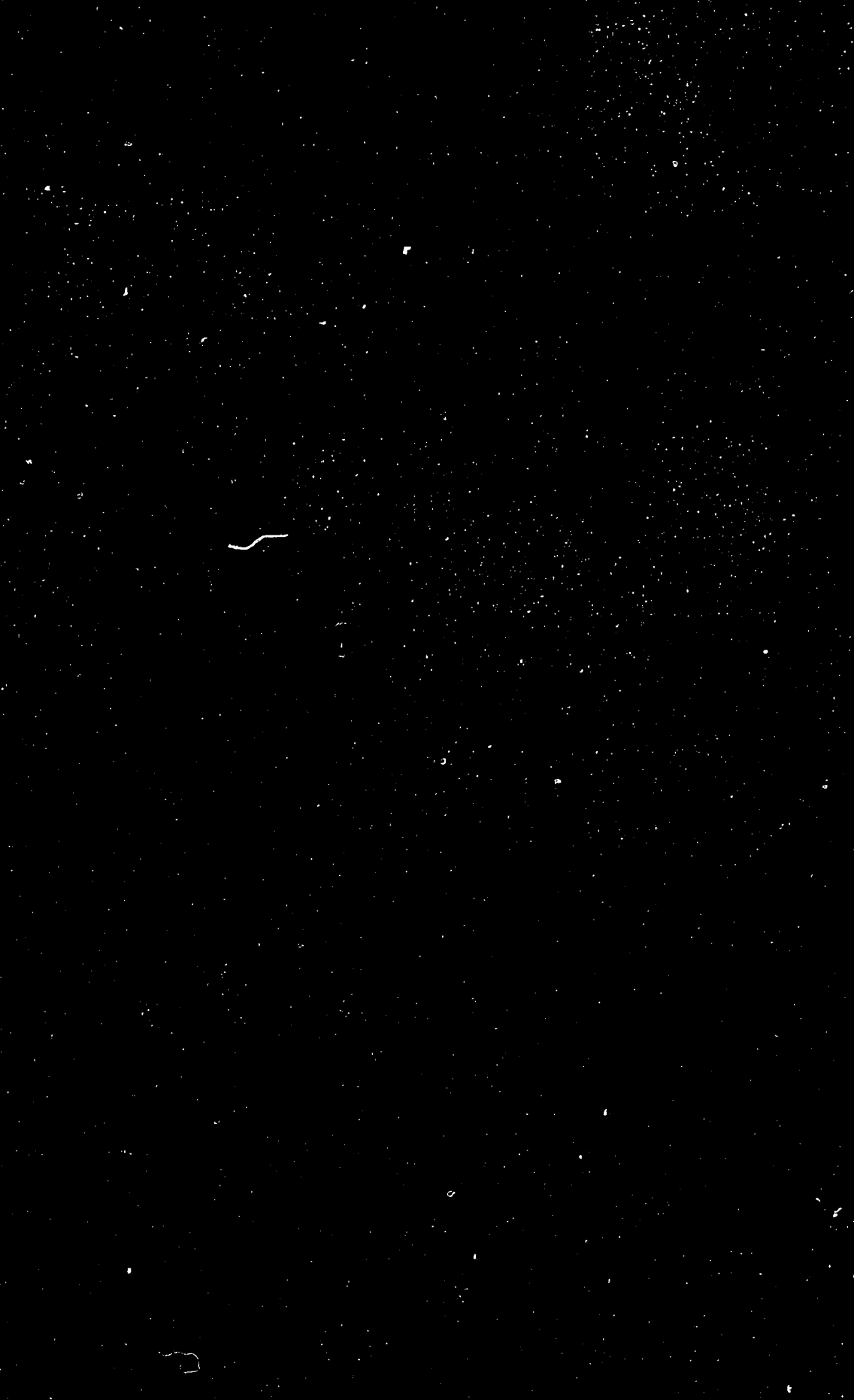


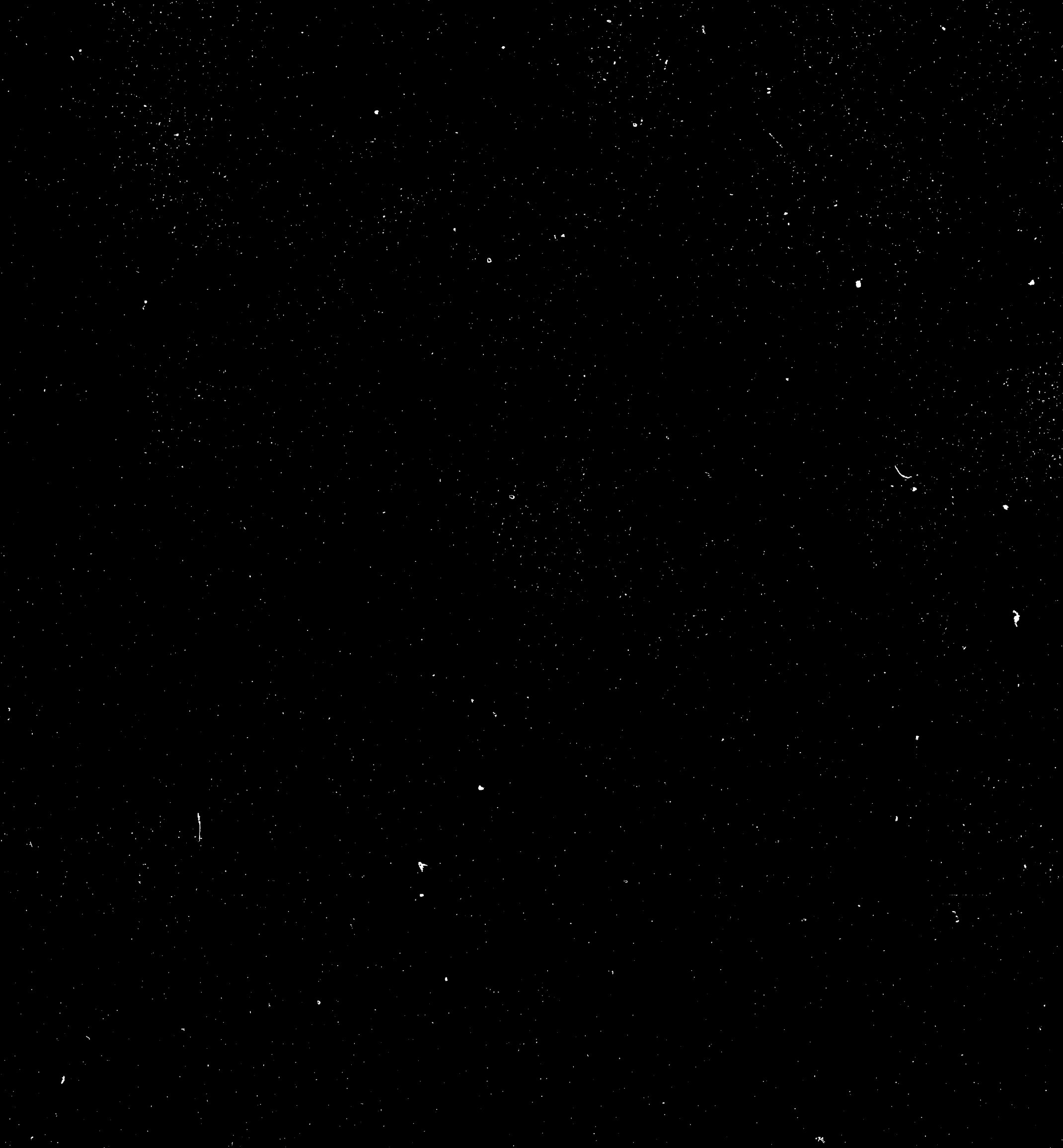




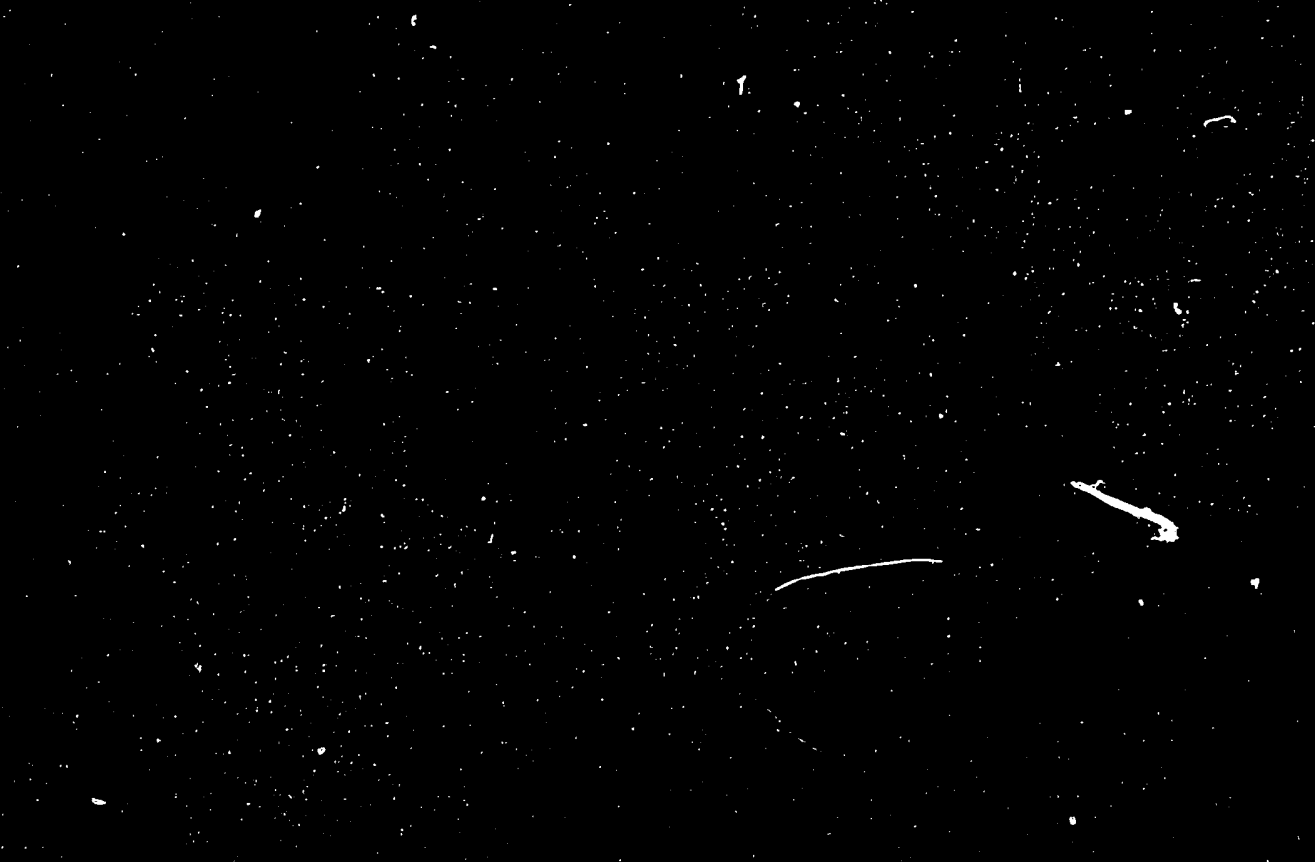

1

4

.

$v_{c}$ 

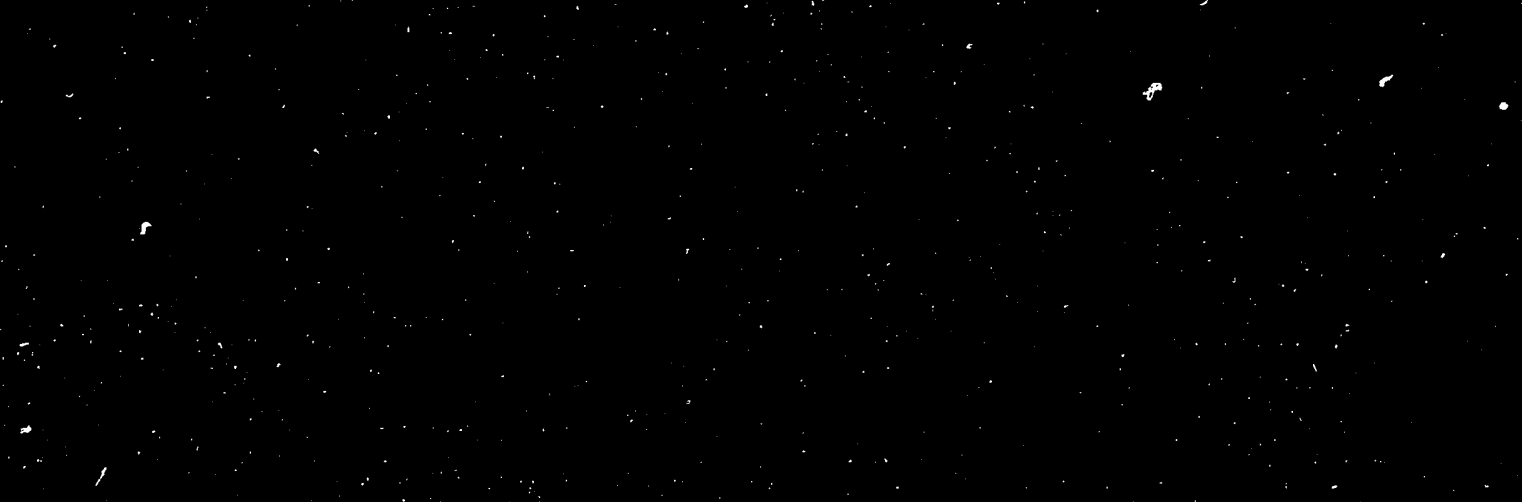

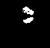

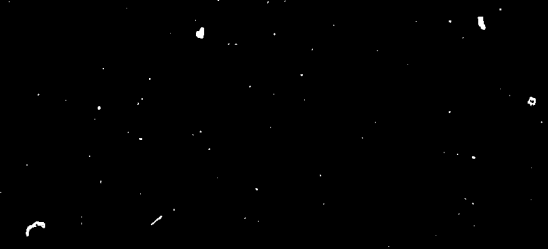

$\Downarrow$ 


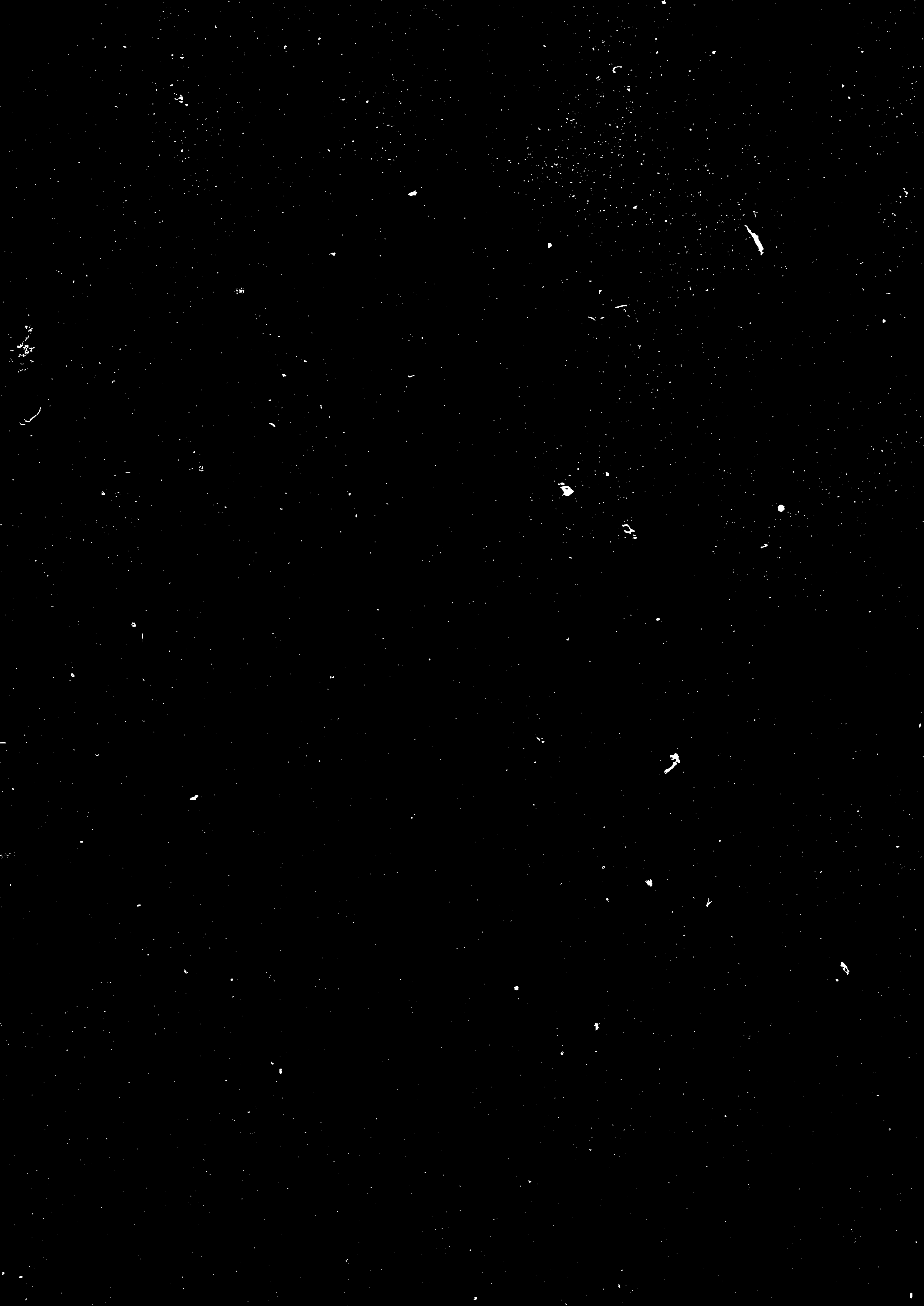

